\title{
Motorized Pedicabs in Indonesia's Legislative Framework
}

\author{
Fachmi Ian Yahya ${ }^{1}$, Noor Fatimah Mediawati ${ }^{2}$, Mochammad Tanzil Multazam ${ }^{3}$ \\ ${ }^{1,2,3}$ Program Studi Hukum, Universitas Muhammadiyah Sidoarjo, Indonesia
}

*fachmi.ian95@gmail.com

\begin{abstract}
The modernization factor has caused the traditional pedicab modified into a motorized pedicab, which raises the pros and cons of the community as well as the law enforcers that regulate legislation in Indonesia. The research problem of this study is "whether there are laws and regulations in Indonesia that specifically regulate motorized pedicabs", and how to classify motorized pedicabs according to Indonesian laws and regulations. This study aims to determine whether there are laws and regulations in Indonesia that regulate motorized pedicabs and determine the classification of motorized pedicabs according to the laws and regulations in Indonesia. This study used a normative juridical design model and the statutory approach. Based on the data analysis, it can be concluded that motorized pedicabs belong to the category of motorized vehicles and their classification is almost the same as two-wheeled motorbike vehicles, but motorized pedicabs have a particular classification to support the safety of drivers and passengers. Many regions in Indonesia have issued regional regulations on motorized pedicabs, such as the cities of Banda Aceh, Langsa, Makassar, Tebing Tinggi, and Langkat Regency.
\end{abstract}

Keywords: Motorized Pedicab, Pedicab, Regional Regulation.

\section{INTRODUCTION}

One example of traditional transportation that is popular and favored by the people in Indonesia is the rickshaw. A pedicab is a modification of a two-wheeled bicycle using a pair of pedals that are pedaled with the feet as the driving force. Serves to transport people and / or goods in small quantities. Then it was modified into a three-wheeled vehicle equipped with a passenger cabin and houses. Pedaling and modernization factors encourage a modified rickshaw with an engine drive or known as a motorized pedicab (bentor). Motorized pedicab is a rickshaw which drives the engine from a motor. The Bentor has been operating in several major cities in Indonesia. [1]

Law Number 22 Year 2009 does not specifically mention or regulate regulations regarding the classification of motorized pedicab vehicles, however modification of motorized pedicab vehicles can be legal as long as they meet the requirements in Article 52 of Law Number 22 Year 2009, namely that they do not endanger traffic safety and disrupt traffic flow. Motorized pedicab vehicles must be subjected to a retype test and are obliged to meet the technical and roadworthiness requirements of motorized vehicles.

It can be said that the motorized pedicab modification is not in accordance with the regulations of Law Number 22 Year 2009 because it does not meet the provisions of motorized vehicle modification. Motorized pedicabs that are not equipped with a driver's license will violate the provisions of Article 77 of Law Number 22 Year 2009. [2] If an area, namely a Regency or City, does not yet have regulations governing motorized pedicabs and wants to make regulations that accommodate or allow the operation of motorized pedicabs in that area, the region can refer to Article 52 of Law Number 2 of 2009 concerning Road Traffic and Transportation jo Article 1 Number 12 Government Regulation Number 55 of 2012 concerning Vehicles, 
regarding Modification of Motor Vehicles which has a definition of changes to the technical specifications of dimensions, engines, and / or the carrying capacity of Motor Vehicles. Law Number 22 Year 2009 does not regulate motorized pedicabs, but regions can refer to Modified Motorized Vehicles because motorized pedicabs are categorized as motorized vehicles if they want to make a regional regulation on motorized pedicabs. [3]

By paying attention to the problem of motorized rickshaws, the writer has a goal, namely to find out whether there are laws that regulate motorized pedicabs and to find out how to classify motorized rickshaws according to legislation in Indonesia.

\section{METHODS}

The type of research used in this paper is to use normative juridical research with primary legal materials and secondary legal materials. The approach to the problem used in this study uses a statute approach (statue approach). Analysis of legal materials carried out is by using systematic interpretation, which is linking laws and regulations with the problems in this study so that conclusions can be obtained from the problems studied by the author.

\section{DISCUSSION}

\subsection{Indonesian Regulations That Regulate Motorized Pedicabs}

Based on Law No.22 of 2009 concerning Road Traffic and Transportation, Article 51 paragraph 2, states that "houses, cargo tanks, trailer trucks, attached carts, and modifications to the type of Motor Vehicle that have passed the type test are issued a ratification decree. design and engineering. " Based on the specifications mentioned in Article 51 paragraph 2, including the characteristics of motorized tricycles in Indonesia.

Several regions have issued local regulations that regulate motorized pedicab operating licenses, including:

\subsection{Makassar City Regional Regulation} Number 14 of 2002 concerning Road Transportation and Licensing Retribution for Internal Transportation of Makassar City

According to Article 6 letter (f) of the Regional Regulation of Makassar City Number 14 of 2002, it is written that motorbikes for rent (ojek), and threewheeled motorbikes (bajaj), pedicab motorbikes, and other similar vehicles are driven by a bicycle motor (engine). motorbikes are given special routes with the characteristic of having a fixed and or unscheduled schedule, serving transportation between areas that are not traversed and / or as a support for the mobility of public transport passengers on each route (main routes, branch routes, branch routes, and direct routes), service slow.

Motorized pedicabs are included in the motorcycle category. Because it is stated in Article 1 of this Perda, namely "a motorcycle is a motorized vehicle with 2 (two) or 3 (three) wheels without houses, either with or without side trains". [4]

\subsection{Tebing Tinggi City Regional Regulation Number 3 of 2007 concerning Retribution for Company Establishment Permits and Motorized Pedicab Operations}

In Article 1 of Tebing Tinggi City Regional Regulation Number 3 of 2007, a motorized tricycle is a three-wheeled vehicle specially assembled and driven by machine tools located on that vehicle. Motorized pedicabs in this regional regulation are divided into two, namely motorized pedicabs to carry people (BBPO), which are three-wheeled vehicles that are driven by machines and equipped with houses that are used to seat people for passengers; as well as a motorized pedicab that carries goods (BBPB), is a three-wheeled vehicle driven by a machine and is equipped with a trailer (place) that is used to transport goods. [5]

\subsection{Langkat Regency Regulation Number 3 of 2007 concerning Transportation Business Permit Retribution}

According to the Regional Regulation of Langkat Nomot 3/2007, a motorized tricycle is a three-wheeled motorized vehicle used to transport people or goods. . In this Perda, motorized pedicabs are non-route transportation. Even though there is no specific route for the operation of motorized pedicabs, motorized pedicabs still pay a levy for transportation business permits, both private property and business entity property. [6]

3.5. Banda Aceh City Qanun Number 8 of
2007 Concerning Amendments to Regional
Regulations of Banda Aceh Level II
Regional Municipality Number 6 of 1999
concerning Route Permit Retribution

3.5. Banda Aceh City Qanun Number 8 of 2007 Concerning Amendments to Regional Regulations of Banda Aceh Level II concerning Route Permit Retribution 
In this Perda, motorized pedicabs include threewheeled vehicles and include public passenger transportation with a maximum capacity of two people. The granting of a route license or operating permit is intended to regulate, control and supervise the balance of Regional transportation services with the aim of realizing road traffic and transportation safely, safely, smoothly, quickly, in an orderly, and orderly manner. [7]

\subsection{Langsa City Qanun Number 13 Year 2008 concerning the License to Operate Motorized Pedicab in Langsa City}

According to the Qanun Kota Langsa No. 13/2008, a motorized rickshaw is a type of vehicle that uses a threewheeled engine with a side tub. The side bin is a passenger or goods seat beside the driver and is a motorized pedicab trailer. [8]

\subsection{Medan City Regional Regulation Number 2 of 2014 concerning Regional Charges in the Transportation Sector.}

In Medan City Regional Regulation No. 2/2014, motorized tricycles are included in the category of motorbikes. This regional regulation states that "a motorcycle is a motorized vehicle with two or three wheels without houses, either with or without side trains".

The purpose of the stipulation of this Perda is to regulate and carry out guidance, supervision and control of the operation of transportation including parking, testing of motorized vehicles, terminals and transportation. [9]

\subsection{The classification of motorized pedicabs according to Indonesian law}

Modification of a motorized tricycle is a threewheeled vehicle that uses human engine power as its driving force which is changed shape and designation according to the wishes and needs of the modifier. These modifications can be in the form of engine modifications, dimensions, and carrying capacity. Apart from that, it must also pay attention to traffic safety. Of course, this modification should not interfere with traffic flow, do not endanger traffic safety, and should not damage the carrying capacity of the road being traversed.

Every motorized vehicle in a complete condition that has passed the type test shall be given a certificate of passing the type test. Then for houses, cargo tanks, trailers, patch cars, and modification of the type of
Motor Vehicle that have passed the type test, a design and engineering ratification decree is issued. The person in charge of manufacturing, assembling and importing the modified vehicle foundation must register the type of production, which will then be given proof of type test registration certificate. After that, the government type test implementing unit will conduct a sample test as a guarantee of conformity to the technical specifications and production against the type test certificate. [10]

The motorized pedicab classification falls into the motorcycle category. Therefore, drivers are required to use a standard helmet. To avoid serious injury when an accident occurs, passengers should also wear a standard helmet provided by the motorized pedicab driver.

\section{CONCLUSION}

In Indonesia, there are several regions that have Regional Regulations on Motorized Rickshaws, namely Banda Aceh, Langsa, Makassar, Tebing Tinggi, Medan and Langkat Regency. Motorized pedicabs are categorized as motorized vehicles. The classification of motorized pedicabs is almost the same as motorbikes for two-wheeled vehicles. However, the difference is that the motorized pedicab has houses and side tubs that are used to transport passengers. In addition, motorized tricycles have a special classification to support driver and passenger safety.

\section{ACKNOWLEDGMENT}

Thank you to Universitas Muhammadiyah Sidoarjo for supporting this research.

\section{REFERENCES}

[1] Meta Suryani, dkk, "Penegakan Hukum terhadap Eksistensi Becak Bermotor Umum (Bentor) berdasarkan Undang-Undang Nomor 22 Tahun 2009 tentang Lalu Lintas dan Angkutan Jalan", Universitas Samudra Langsa. Aceh, pp. 36, 2016.

[2] Nizul Mutok, dkk, "Kajian Yuridis Normatif terhadap Pengemudi Kendaraan Becak Bermotor Menurut Pasal 47 Junctis Pasal 77 dan Pasal 281 Undang-Undang Nomor 22 Tahun 2009 tentang Lalu Lintas dan Angkutan Jalan", Universitas Brawijaya, pp. 10, 2014.

[3] M. Hardyan Desmawanto, dkk, "Eksistensi Peraturan Daerah tentang Becak bermotor", Artikel Skripsi Universitas Brawijaya, pp. 10-11, 2014.

[4] Peraturan Daerah Kota Makassar Nomor 14 Tahun 2002 Tentang Angkutan Jalan Dan Retribusi Perizinan Angkutan Dalam Kota Makassar 
[5] Peraturan Daerah Kota Tebing Tinggi Nomor 3 Tahun 2007 Tentang Retribusi Izin Mendirikan Perusahaan Dan Operasi Becak Bermotor

[6] Peraturan Daerah Kabupaten Langkat Nomor 3 Tahun 2007 Tentang Retribusi Izin Usaha Angkutan

[7] Qanun Kota Banda Aceh Nomor 8 Tahun 2007 Tentang Perubahan Atas Peraturan Daerah Kotamadya Daerah Tingkat Ii Banda Aceh Nomor 6 Tahun 1999 Tentang Retribusi Izin
Trayek

[8] Qanun Kota Langsa Nomor 13 Tahun 2008 Tentang Ijin Pengoperasian Becak Bermotor Dalam Kota Langsa

[9] Peraturan Daerah Kota Medan Nomor 2 Tahun 2014 Tentang Retribusi Daerah Di Bidang Perhubungan

[10] Undang-Undang Nomor 22 Tahun 2009 Tentang Lalu Lintas Dan Angkutan Jalan 